\title{
Analisis Perbandingan Konsep Subyek Antara Bahasa Arab dan Bahasa Indonesia
}

\author{
Dini Handayani \\ Institut Agama Islam Negeri (IAIN) Syekh Nurjati Cirebon \\ dinnainei@gmail.com \\ Erfan Gazali \\ Institut Agama Islam Negeri (IAIN) Syekh Nurjati Cirebon \\ erfangazali@gmail.com
}

\begin{abstract}
Abstrak
Bahasa-bahasa yang ada di dunia ini adalah sama karena di dasari oleh satu sistem yang universal. Namun, masing-masing bahasa memiliki karakteristik yang berbeda, contohnya dalam segi tata bahasa. Setiap bahasa pasti memiliki kedudukan dalam kalimat seperti subyek, predikat, obyek. Namun, karakteristiknya masing-masing berbeda antara bahasa satu dan lainnya. Seperti subyek, dalam bahasa Indonesia hanya ada satu jenis dan satu nama. Sementara dalam bahasa Arab, memiliki ragam sinonim dan jenis. Penting bagi kita untuk mengetahui dan memahami keduanya agar tidak ada penyempitan maupun penghilangan makna di salah satu bahasa tersebut.Maka dari itu, perlu diadakan perbandingan antara subyek dalam bahasa Arab dan bahasa Indonesia. Beberapa penelitian tentang perbandingan dua bahasa telah banyak dilakukan, tetapi bukan pada ranah fungsi sintaksis khususnya perbandingan subyek antara bahasa Arab dan bahasa Indonesia. Oleh sebab itu, kajian ini akan membahas perbandingan tentang konsep subyek antara bahasa Indonesia dan bahasa Arab. Kajian ini menggunakan pendekatan kualitatif deskriptif dengan jenis penelitian "Library Reseacrh". Teknik pengumpulan datanya menggunakan triangulasi yaitu menggabungkan teknik wawancara, observasi dan dokumen. Hasil dari kajian ini adalah, terdapat perbedaan pada pengertian, jenis, beberapa karakteristik dan beberapa unsur pembentuk subyek antara bahasa arab dan bahasa Indonesia serta terdapat persamaan pada beberapa karakteristik dan beberapa unsur pembentuk subyek antara bahasa arab dan bahasa Indonesia.
\end{abstract}

Kata Kunci: Subyek, Musnad Ilaih, bahasa Arab, bahasa Indonesia

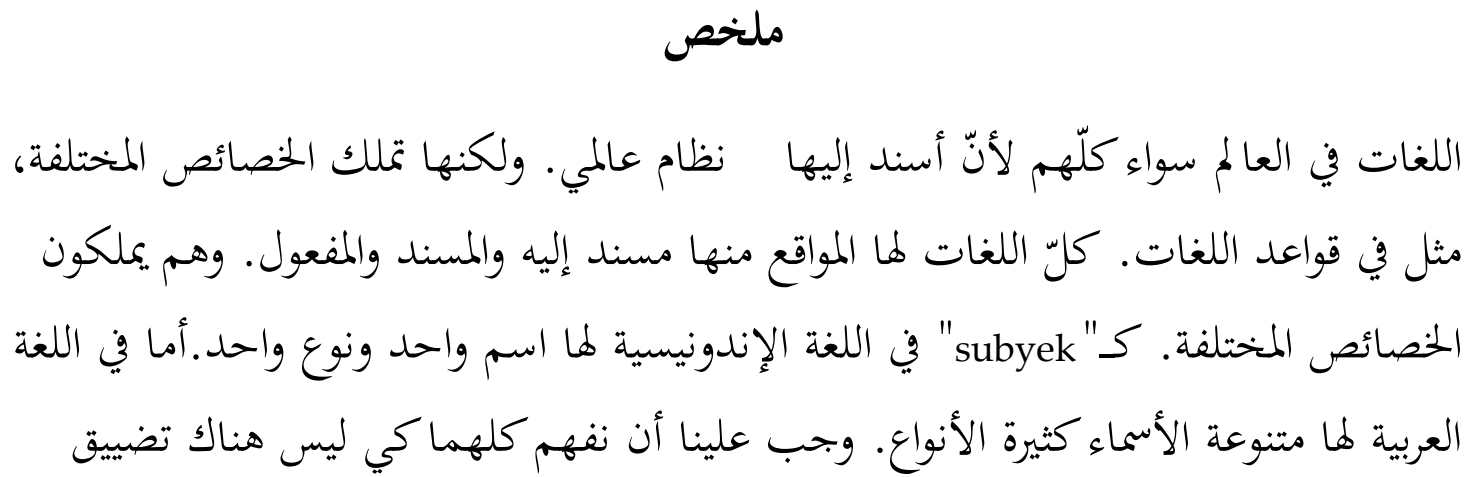




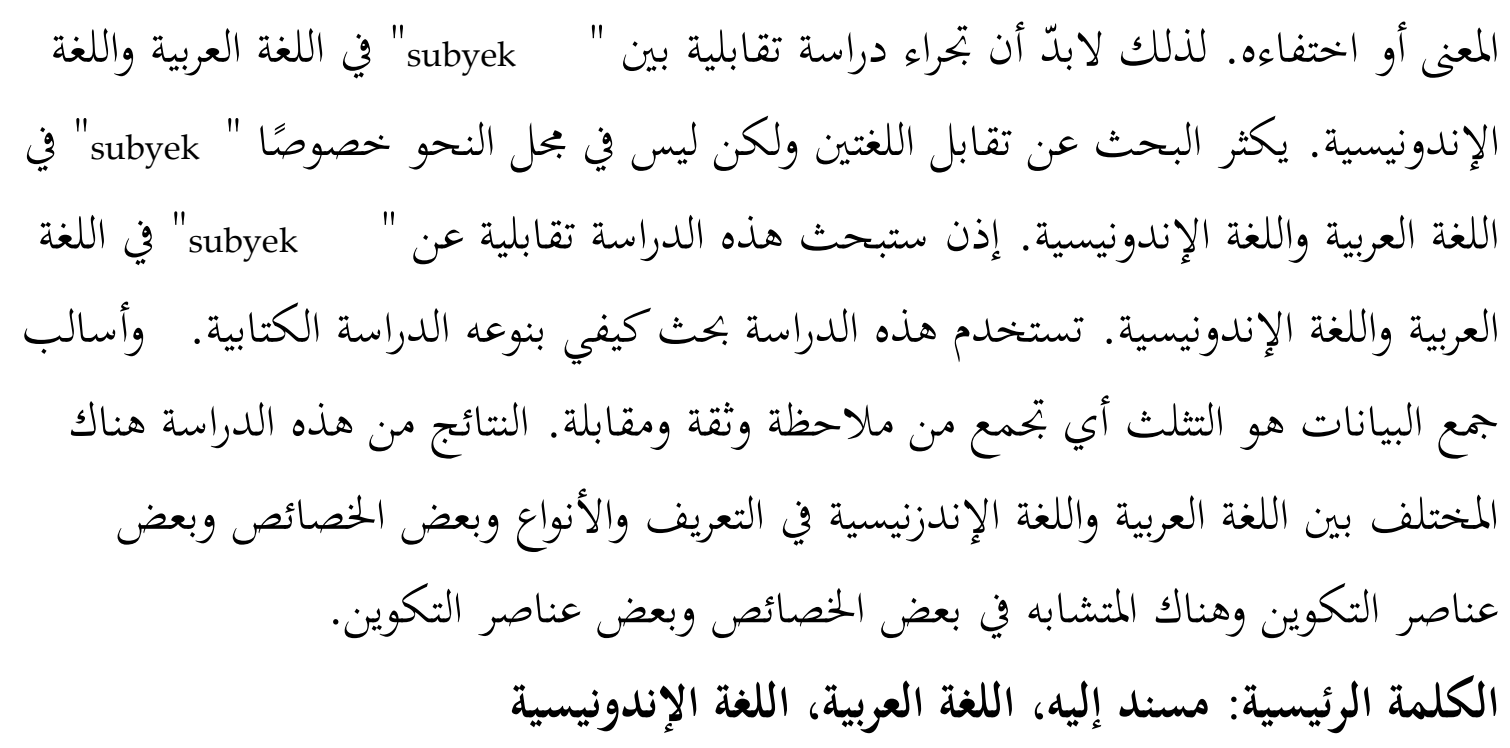

\section{Pendahuluan}

Bahasa sangat penting dalam kehidupan manusia. Tanpa bahasa setiap kegiatan manusia tidak akan berjalan, karena bahasa adalah alat komunikasi yang digunakan oleh sekelompok orang untuk menyampaikan tujuan. Pun dengan ilmu pengetahuan, tidak akan berkembang jika tidak dibahasakan. Oleh sebab itu, bahasa dikatakan sebagai jendela dunia karena berbagai pengetahuan dan 1001 peradaban ada dan tercipta karena dibahasakan'.

Pada dasarnya semua bahasa terdiri dari struktur dalam dan struktur luar. Noam Chomsky dengan hipotesis nurani-nya mengatakan bahasa-bahasa yang ada di dunia ini adalah sama karena di dasari oleh satu sistem yang universal ${ }^{2}$. Sistem yang universal di sini hanya terdapat di bagian struktur dalam bahasa. Yang termasuk ke dalam struktur dalam bahasa adalah leksikon (komponen semantik) dan gramatika (komponen morfologi dan komponen sintaksis) di mana komponen-komponen tersebut berada di dalam otak, yang berarti struktur dalam bahasa berhubuCngan erat dengan tata bahasa dan makna setiap bahasa. Bagaimana bahasa tersusun, dan bagaimana memaknai sebuah bahasa lalu menyusunnya.

Penting bagi setiap pembelajar bahasa Arab maupun bahasa Indonesia mempelajari sintaksis, mengingat sintaksis adalah salah satu cabang tata bahasa yang menelaah struktur-struktur kalimat, klausa, dan frase agar mampu menempatkan kata sesuai dengan fungsinya ${ }^{3}$. Asrori dalam bukunya menjelaskan bahwa sintaksis mengkaji hubungan antara kata yang satu dengan

1 Fitria Rif'atul azizah. Analisis Pemikiran Ibnu Khaldun Terhadap Direct Method Dalam Pembelajaran Bahasa Asing. (Skripsi. Cirebon: IAIN Syekh Nurjati 2016)(Tidak dipublikasi). Hal. 1.

2 Abdul chaer. Buku Sintaksis Bahasa Indonesia. (Jakarta: PT. Rineka Cipta,2009). Hal. 57.

${ }^{3}$ Henry Guntur Tarigan. Pengajaran Sintaksis.(Bandung: Angkasa, 2009). Hal. 4. 
kata yang lainnya, contohnya pada konstruksi Aminah istri Ahmad pergi ke plaza. Dari konstruksi tersebut bisa dicari hubungan antara (a) Aminah istri Ahmad dan pergi ke plaza, (b) Aminah dan istri Ahmad, dan (c) pergi dan ke plaza 4 .

Bahasa Arab maupun bahasa Indonesia memiliki fungsi sintaksis yang sama dalam struktur kalimatnya yaitu subyek, predikat, obyek, dan keterangan. Namun, mengingat salah satu karakteristik bahasa adalah unik dan universal, maka masing-masing bahasa tersebut memiliki ke-khasan tersendiri ${ }^{5}$. Hal ini bisa terlihat dari konsep maupun istilah masing-masing fungsi yang berbeda.Banyak orang memahami bahwa subyek dalam bahasa Arab adalah fa'il. Sebagaimana dialog yang penulis lakukan pada beberapa mahasiswa jurusan bahasa Arab dan jurusan lainnya, hampir semua berpendapat bahwa "subyek" dalam bahasa Arab adalah fa'il. Padahal Asrori menyebutkan bahwa "subyek" dalam bahasa Arab dipadankan dengan istilah Musnad Ilaih. Dan Musnad Ilaih sendiri terdiri dari Mubtada', Fa'il, Na'ib Fa'il, Ism Inna dan Ism $K a a n a^{6}$. Pemahaman ini akan menyebabkan penyempitan makna subyek bahasa Arab.Selain itu, para pelajar bahasa akan terus terperosok dalam pemahaman yang umum.

Untuk mendapatkan solusi atas permasalahan tersebut, maka perlu diadakan analisis perbandingan konsep subyek antara bahasa Arab dan bahasa Indonesia agar makna dan konsep subyek mampu di fahami oleh pelajar bahasa dengan pemahaman yang tepat dan semestinya. Oleh karena itu, kajian ini lebih condong menggunakan pendekatan kualitatif deskriptif jenis library Research / studi pustaka karena pembahasannya akan dipaparkan berupa narasi dan analisisnya diarahkan kepada buku-buku dan tulisan-tulisan yang berkaitan dengan pembahasan.

\section{Subyek dalam Bahasa Arab}

Subyek adalah bagian kalimat yang menunjukkan pelaku, tokoh, sosok (benda), sesuatu hal, suatu masalah yang menjadi pangkal/pokok pembicaraan ${ }^{7}$. Dalam bahasa Arab istilah yang paling umum di fahami sebagai subyek adalah fa'il.Padahal, Asrori menyebutkan bahwa subyek dalam bahasa Arab adalah musnad ilaih, yang kemudian terbagi lagi ke dalam lima jenis yaitu; fa'il, na'ib fa'il, mubtada', ism Inna, dan ism Kaana. Namun pendapat lain menyebutkan bahwa musnadilaih dibagi ke dalam tujuh jenis yaitu; fa'il, na'ib fa'il, mubtada', ism Inna, ism Kaana, ism huruf yang beramal seperti amalan 'laisa',

${ }^{4}$ Imam Asrori. Sintaksis Bahasa Arab. (Malang: Penerbit Misykat, 2004).Hal. 26.

${ }^{5}$ Imam Asrori. Sintaksis Bahasa Arab. ... Hal. 13.

${ }^{6}$ Imam Asrori. Sintaksis Bahasa Arab. ... Hal. 74.

7IkraamNnimas. Makalah Bahasa Indonesia Kalimat Efektif. (Paper Academia Edu, 2014) (dipublikasi). Hal. 3.

${ }^{8}$ Imam Asrori. Sintaksis Bahasa Arab. (Malang: Penerbit Misykat, 2004). Hal. 73. 
ism La an-nafiyah Lil jinsi ${ }^{9}$. Jadi, istilah fa'il hanya bagian dari penyebutan subyek secara umum.

Berikut contoh subyek dalam bahasa Arab yang selanjutnya disepakati bahwa subyek dalam bahas Arab adalah musnad ilaih
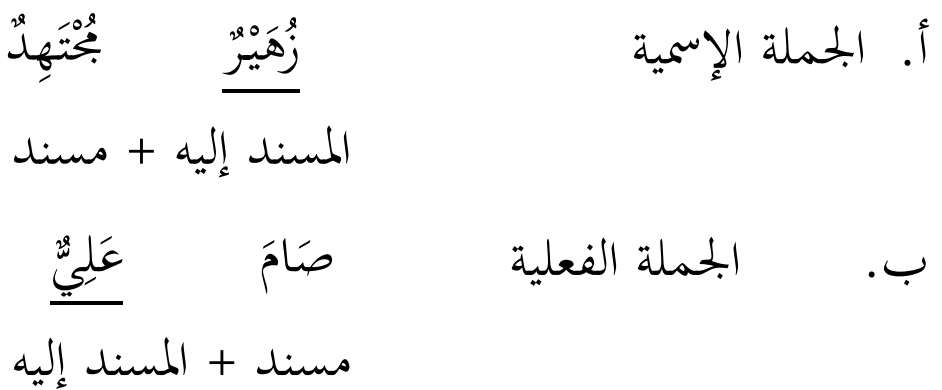

Dalam bahasa Arab kita mengenal ada dua jumlah yaitu jumlah ismiyyah dan jumlah fi'liyyah, yang mana kedua jumlah tersebut masing-masing terdiri dari musnad dan musnad ilaih. Hanya saja letak penempatan fungsi sintaksisnya tidak sama.Sebagaimana kita lihat pada contoh di atas, dalam jumlah ismiyyah, musnad ilaihterletak diawal jumlah dan sebelum musnadyang selanjutnya bisa juga disebut mubtada'. Sementara dalam jumlah fi'liyyah, musnad ilaih terletak setelah musnad yang selanjutnya disebut dengan $f a^{\prime} i l$.

Gulayaini menyebutkan musnad ilaihi adalah maa hukimat 'alaihi bisyai' maksudnya adalah segala sesuatu yang dihukumi atau ditandai oleh suatu hal.Pada dasarnya,musnad ilaih selalu beri'robrafa'. Namun, terkadang bisa juga beri'robnashab dan khofad tergantung keadaan fungsi atau kedudukan musnad ilaih itu sendiri ${ }^{11}$.

Contoh:
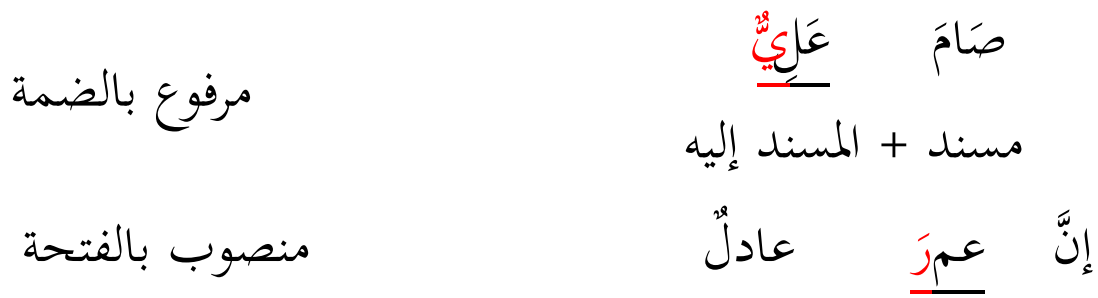

${ }^{9}$ Mushtofa Al-Gulayaini, Jami'uddurus Al-Lughah Al-'Arobiyah. (Kairo: daarul hadis, 2005). Hal. 11.

${ }^{10}$ Mushtofa Al-Gulayaini, Jami'uddurus Al-Lughah Al-'Arobiyah. (Kairo: daarul hadis, 2005). Hal. 11.

${ }^{11}$ Istilah i'rob dalam bahasa Inggris disebut dengan Grammatical case. Padanannya rafa' = nominative case, $n a s h a b=$ accusative case, $k h o f a d=$ genitive case. Dalam bahasa Indonesia bisa dipadankan dengan peran sintaksis. Sebagaimana fillmore pada tahun 1968 memperkenalkan tata bahasa kasus dan ia membagi kasus ke dalam sepuluh kasus yaitu; 1) Kasus Agentif (A) / Pelaku; 2) Kasus Experiens / Pengalam (P); 3) Kasus Instrumen (I) / Alat; 4) Kasus Objektif (O); 5) Kasus Sebab (S); 6) Kasus Tujuan (Tj); 7) Kasus Lokatif / tempat (T); 8) Kasus waktu (WK); 9) Kasus Penyerta (PNY); 10) Kasus Benefaktif (BEN). 

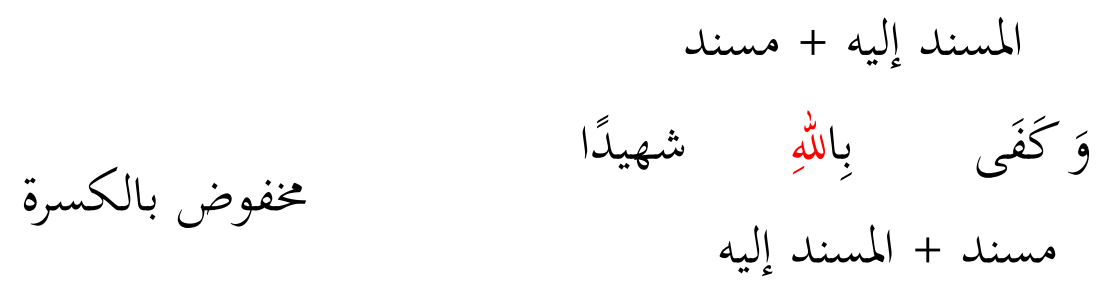

Seperti yang telah disebutkan di muka, bahwa subyek dalam bahasa Arab memiliki beberapa jenis. Menurut Asrori musnad ilaih terbagi ke dalam fa'il, na'ib fa'il, mubtada', ism Inna, dan ism Kaana. Sedangkan, mennurut Gulayaini dan Khoironi terbagi ke dalam tujuh yaitu ; fa'il, na'ib fa'il, mubtada', ism Inna, ism Kaana, ism huruf yang beramal seperti amalan 'laisa', ism La an-nafiyah Lil jinsi.

Berikut contoh dari masing-masing jenis musnad ilaih:

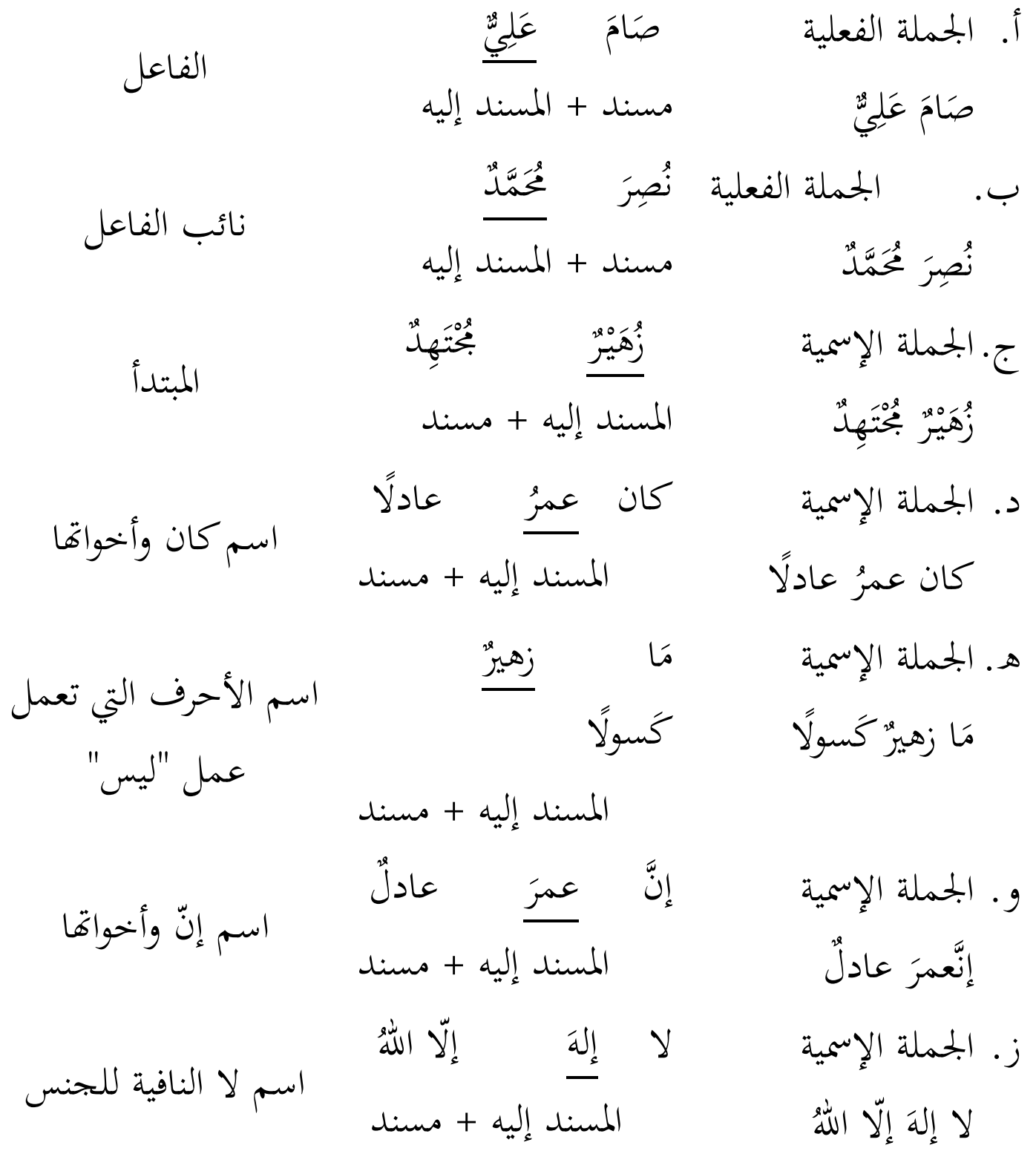




\section{$F a^{\prime} i l$}

Fa'il adalah isim yang terletak setelah fi'il ma'lum (kata kerja aktif) dan menunjukkan siapa yang melakukan pekerjaan tersebut seperti "اجتهد زهيرء) Zuhair bersungguh-sungguh ${ }^{12}$.Letaknya adalah pada jumlah fi'liyyah. Dahlan dalam matan al-ajurumiyah menyebutkan bahwa fa'il adalah isim marfu' yang

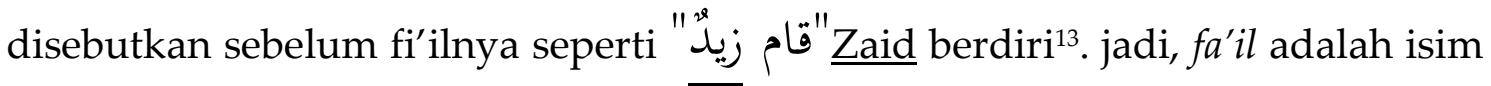
marfu' yang terletak sebelum fi'il ma'lum (kata kerja aktif) dan menunjukkan pada siapa yang melakukan pekerjaan.

Berikut adalah hukum dan karakteristik fa'il menurut para ahli nahwu:

1. Harus di rafa'kan

2. Terletak setelah musnad (predikat). Namun, bisa juga di awal jika fa'il berbentuk isim dhomir

3. Fa'il harus ada dalam jumlah

4. Fa'il tetap ada dalam jumlah meski terkadang fi'il nya di hilangkan

5. Dalam jumlah fi'liyyah, fa'il tidak mempengaruhi fi'il dalam hal kuantitasnya

6. Pada dasarnya $f a^{\prime} i l$ terletak sebelum maf'ul, namun terkadang $f a^{\prime} i l$ terletak setelah maf'ul

7. Jika fa'il nya muannats, maka di muannatskan fi'il nya

8. Memiliki makna 'apa' dan 'siapa'

9. Merupakan unsur yang sangat penting yang harus ada dalam jumlah

Fa'il dibagi menjadi dua:

1) Fa'il berupa isim shorih, terdiri dari:

- Isim dhohir

- Isim dhomir

- Isim isyaroh

- Isim maushul

2) Fa'il berupa isim muawwal bishorih, yaitu:

- Fi'il mudhori' yang di dahului oleh huruf-huruf mashdariyah seperti أنَ

- Isim Inna dan khobarnya

\section{Naib Fa'il}

Sama seperti fa'il, na'ib fa'il terletak pada jumlah fi'liyyahNa'ib fa'il adalah isim marfu' yang terletak setelah fi'il majhul (kata kerja pasif) dan

12 Mushtofa Al-Gulayaini, Jami'uddurus Al-Lughah Al-'Arobiyah. (Kairo: daarul hadis, 2005). Hal. 353.

${ }^{13}$ Dahlan, Matan al-ajurumiyah.... Hal. 13. 
menunjukkan kepada seseorang yang diletakkan atasnya fi'il, yaitu isim yang menggantikan $f a^{\prime} i l$ setelah ia dihilangkan. $N a^{\prime} i b$ fa'il di rafa'kan setelah sebelumnya di nashabkan karena setiap sesuatu yang digantikan maka hukumnya ikut digantikan. Contoh, "يُكْرُمُ الْمُجْتَهِهُ "Orang yang bersungguhsungguh di muliakan ${ }^{14}$. Pendapat lain mengatakan bahwa na'ib fa'il adalah isimmarfu' yang menempati tempatnya fi'il setelah fi'il tersebut dihilangkan ${ }^{15}$.Intinya, $n a^{\prime} i b f^{\prime} i l$ adalah maf'ul yang menggantikan fa'ilakibat $f a^{\prime} i l$ nya dihilangkan maka i'rob nya maf'ul yang tadinya nashab berubah sesuai i'rob fa'il yaitu rafa'.

Berikut adalah hukum dan karakteristik $f a^{\prime} i l$ menurut para ahli nahwu:

1. Jika na'ibfa'il menggantikan fa'il yang fi'ilnya fi'il madhi, maka fi'il madhi tersebut diubah ke fi'il majhul dengan cara di dhammahkan awalnya dan di kasrahkan huruf sebelum akhirnya. Namun, jika fi'il mudhori' maka dhammahkan awalnya dan di fathahkan huruf sebelum akhirnya

2. Jika na'ib fa'il muannats maka fi'il nya muannats

3. Harus di rafa'kan

4. Merupakan maf'ul yang menempati tempatnya fa'il

5. Memiliki makna 'apa' dan 'siapa'

6. Merupakan unsur yang sangat penting yang harus ada dalam jumlah $N a^{\prime} i b$ fa'il dibagi menjadi:

1) Isim shorih

- Isim dhohir

- Isim isyaroh

- Isim maushul

2) Isim dhomir

- Dhomir Bari

- Dhomir mustatir

3) Mashdar muawwal

- Fi'il yang di dahului أََْ

- Isim Inna dan khobarnya

4) Syibhul jumlah

- jar majrur

- tarkib washfi

- tarkib idhofi

- tarkibul 'ilmiyyah

14 Mushtofa Al-Gulayaini, Jami'uddurus Al-Lughah Al-'Arobiyah. (Kairo: daarul hadis, 2005). Hal. 11.

${ }^{15}$ Ibrahim Syamsuddin. Marja'u ath-thullabi Fiji qawa'id al-lughah. (Libanon: daarul kutub al-`alamiyah,1971). Hal. 180. 


\section{Mubtada'}

Tidak seperti fa'il dan na'ib fa'il, mubtada' terletak pada jumlah ismiyyah. Pengertian mubtada' itu sendiri adalah isim yang diberitakan ${ }^{16}$, dalam hal ini mubtada' diberitakan oleh khobar. Syamsuddin menjelaskan bahwa mubtada' adalah isim yang mengawali jumlah ismiyyah ${ }^{17}$. Khoironi menambahkan bahwa mubtada' adalah isim yang di rafa'kan dan tidak

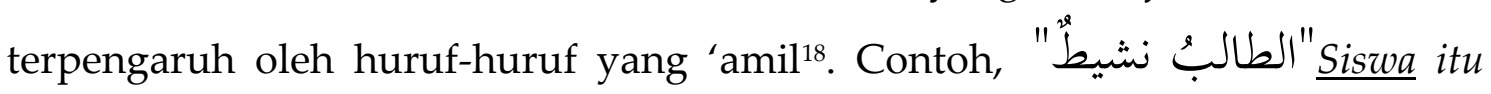
rajin.

Berikut adalah hukum dan karakteristik mubtada' menurut para ahli nahwu:

1. Terletak di awal jumlah

2. Harus di rafa'kan. Namun, terkadang bisa di jar'kan

3. Harus ma'rifat / definit / takrif

4. Tidak bisa di pengaruhi oleh huruf 'awamil.

5. Terkadang mubtada' bisa dihilangkan jika ia berupa kalimat jawaban

6. Pada dasarnya mubtada' terletak sebelum khobar. Namun, terkadang mubtada' di letakkan di akhir setelah khobar.

Mubtada'dibagi menjadi dua:

1) Mubtada' isim shorih

- Dhomir munfashil

- Isim 'alam

- Isim isyaroh

- Isim maushul

- Isim ma'rifat dengan ال

- Idhafah

2) Mubtada' muawwal; Tersusun dari fi'il yang di dahului أَْْ

\section{Ism Kaana wa Akhwatuha}

Isim kaana terletak pada jumlah ismiyyah. Ia adalah isim yang terletak diawal jumlah ismiyyah seperti mubtada', hanya saja ia di dahului oleh salah

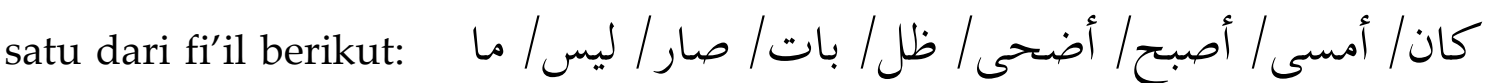

${ }^{16}$ Mushtofa Al-Gulayaini, Jami'uddurus Al-Lughah Al-'Arobiyah. (Kairo: daarul hadis, 2005). Hal. 33.

${ }^{17}$ Ibrahim Syamsuddin. Marja'u ath-thullabi Fiji qawa'id al-lughah. (Libanon: daarul kutub al-'alamiyah,1971). Hal. 30.

${ }^{18}$ Agus Shohib Khoironi, Awdhohul Manahij fii Mu'jami al-lughah al-'arobiyah. (Jakarta: WCM Press, 2007). Hal. 150. 


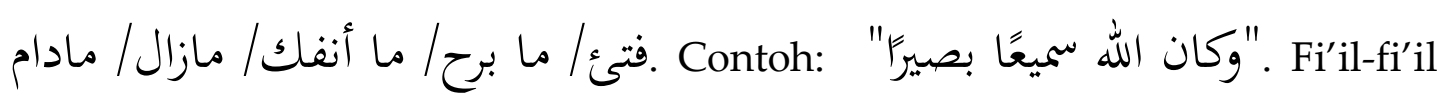
tersebut disebut oleh Gulayaini sebagai fi'il naqish, yaitu fi'il yang mendahului mubtada' khobar / jumlah ismiyyah ${ }^{19}$.Jadi, isim kaana adalah setiap mubtada' yang di dahului oleh fi'il-fi'il naqish yang tersebut diatas.

Hukum dan karakteristik isim kaana menyerupai hukum fa'il, yaitu:

1. Harus rafa'

2. 'Fi'il naqish tetap mufrod meski isim nya mutsanna atau jama'

3. Pada dasarnya isim kaana terletak lebih dahulu daripada khobarnya, tetapi terkadang malah sebaliknya.

4. Jika isim kaana muannats, maka di muannatskan pula fi'il naqish nya.

5. Karakteristik lain yang tidak sama dengan fa'il dan menjadi ciri khusus isim kaana yaitu merafa'kan mubtada' dan menashabkan khobar.

Seperti yang telah dijelaskan di muka, Asrori menyebutkan bahwa subyek dalam bahasa Arab hanya ada lima sedangkan pendapat lainnya menyebutkan ada tujuh. Hal ini bisa dilihat bahwa alasan Asrori menggabungkan isim kaana dengan isim huruf-huruf yang beramal seperti amal laisa karena laisa merupakan bagian dari kaana wa akhwatuha. Sementara itu, pendapat lain yang memisahkan keduanya berpendapat karena laisa adalah satu-satunya yang memiliki makna nafyun.

\section{Ism Huruf-huruf yang Beramal seperti Laisa}

Dapat kita ketahui bahwa laisa merupakan bagian dari fi'il-fi'il naqish yang menjadi akhwat kaana, dan fi'il-fi'il tersebut memiliki makna yang berbeda. Makna laisa sendiri adalah nafyun yaitu bermakna meniadakan keadaan. Keterangan lain juga menyebutkan laisa adalah fi'il madhi yang berfungsi untuk meniadakan khususnya isim, ia juga disebut sebagai fi'il yang menyerupai huruf ${ }^{20}$.

Berikut adalah huruf-huruf yang menyerupai amal laisa menurut Khoironi ${ }^{21}$ :
1. Maa an-nafiyah
2. Laa an-nafiyah lilwahidah
3. In an-nafiyah
4. Laata an-nafiyah

\section{Ism Inna wa Akhwatuha}

19 Mushtofa Al-Gulayaini, Jami'uddurus Al-Lughah Al-'Arobiyah. (Kairo: daarul hadis, 2005). Hal. 386.

${ }^{20}$ Mushtofa Al-Gulayaini, Jami'uddurus Al-Lughah Al-'Arobiyah..... Hal. 385.

${ }^{21}$ Agus Shohib Khoironi, Awdhohul Manahij fii Mu'jami al-lughah al-'arobiyah. (Jakarta: WCM Press, 2007). Hal. 178. 
Isim inna terletak pada jumlah ismiyyah, karena ia adalah mubtada' yang di dahului oleh huruf inna wa akhwatuha yaitu: إنّ/ أنّ/ كأنّ/ لك كنّ/ ليت

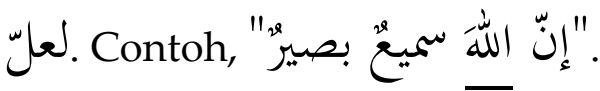

Hukum dan karakteristik isim kaana menyerupai hukum fa'il, yaitu:

1. Untuk penulisan Inna di awal jumlah posisi hamzah berada di bawah (峁)

2. Jika Inna berada ditengah jumlah maka posisi hamzah berada di atas (أَنَ)

3. Menashabkan mubtada' dan merafa'kan khobar.

4. Dhomir yang tersambung pada Ina disebut isim Inna.

5. Isim inna tidak bisa dihilangkan sewaktu-waktu, tetapi khobarinna bisa.

Ism Laa An-Nafiyah Lil Jinsi

Laa An-Nafiyah Lil Jinsi adalah huruf yang digunakan untuk meniadakan isim setelahnya. Kaidah atau hukumnya menyerupai inna yaitu menashabkan isim dan merafa'kan khabar. Hanya saja isim yang di nashabkannya harus nakiroh. Dahlan dalam matan al-ajurumiyah menjelaskan bahwa Laa an-nafiyah lil jinsi menashabkan isim tanpa tanwin ${ }^{22}$. Maksudnya, meski isim yang sebelum di nashabkan adalah nakiroh (bertanwin) namun ketika ada Laa an-nafiyah lil jinsi mendahuluinya tidak bertanwin. Begitu pula, jika isim sebelumnya berلl, telah di dahului Laa an-nafiyah lil jinsi tidak lagi berll.

\section{Subyek dalam Bahasa Indonesia}

Telah sedikit disinggung di awal, bahwa subyek adalah bagian kalimat yang menunjukkan pelaku, tokoh, sosok (benda), sesuatu hal, suatu masalah yang menjadi pangkal/pokok pembicaraan. Lubis dalam bukunya mengatakan subyek adalah bagian kalimat yang berwujudkan kata benda atau nomina yang menjadi pelaku dari satu pekerjaan pada kalimat aktif ${ }^{23}$. Contoh: Saya mengarang cerita. Sayaadalah subyekmengarangadalah predikatceritaadalah objek.

Berikut pengertian subyek dalam bahasa Indonesia menurut beberapa ahli:

${ }^{22}$ Ahmad Zaini Dahlan. Matan al-ajurumiyah. (Surabaya: Maktabatu Muhammad bin nabhan wa Awladihi). Hal. 13.

${ }^{23}$ Hamid Hasan Lubis. Glosarium Bahasa dan Sastra. (Bandung: Angkasa, 1994). Hal. 133. 
1) Khairah dan Ridwan mengatakan subyek adalah bentuk gramatikal di dalam klausa yang berpotensi berperan sebagai pelaku, peruntung, ukuran, pengalaman dan pokok.

2) Putrayasamengatakan subyek adalah sesuatu yang dianggap berdiri sendiri dan yang tentangnya diberitakan sesuatu.

3) Kridalaksana mengatakan subyek adalah bagian klausa yang menandai apa yang dikatakan oleh pembicara.

4) Kosasih menyebutkan bahwa subyek adalah Unsur yang berfungsi sebagai pokok pembicaraan suatu kalimat. Contoh: Lalan licin berbahaya.

Pembicara membicarakan Jalan licin. Bagian ini disebut subyek

Contoh lain:

$\underline{\text { Kedua anggota DPR }}$

1.

itu

S/Frasa.Nomina/Pela

Berkelakar

$\mathrm{ku}$

2.

Masyarakat

S/Nomina/Pengalama

Fobia

$\mathrm{P}$

$\frac{\text { Pada Nuklir }}{\mathrm{K}}$

$\mathrm{n}$

3.

Ia

S/Pronomina/Peruntu

Mendapat

$\mathrm{P}$

Nilai bagus

$\mathrm{O}$

ng

Dari pengertian tersebut di atas, dapat diambil kesimpulan bahwa subyek adalah unsur yang menjadi pokok pembicaraan dalam suatu kalimat. Misal,

1. Guru itu sedang mengajar

Guru itu menjadi unsur utama dalam kalimat tersebut.

2. Buku yang berwarna merah adalah milikku

Buku yang berwarna merah menjadi unsur utama dalam kalimat tersebut.

Perlu diketahui disini bahwa dalam bahasa Indonesia, subyek hanya memiliki satu jenis meski letak nya berada tidak hanya pada satu kalimat. Begitu pula penamaannya, tidak memiliki ragam sinonim seperti dalam bahasa arab.

\section{Karakteristik Subyek}

Berikut akan dipaparkan ciri-ciri dan karakteristik Subyek dalam bahasa Indonesia menurut beberapa referensi:

1. Untuk menandai subjek dalam satu klausa dapat dilakukan dengan menggunakan kata tanya apa atau siapa. Jawaban dari apa atau siapa merupakan subjek. Contoh:

a. Siapa (yang) berkelakar?

b. Siapa (yang) fobia pada nuklir? 
c. Apa (yang) penting bagi setiap calon presiden?

d.Apa (yang) menyehatkan badan?

Sebagaimana Rahardi ${ }^{24}$ menyebutkan bahwa salah satu cara untuk mengetahui subyek adalah dengan menggunakan pertanyaan:

- Siapa + yang + predikat, apabila subyek itu adalah subyek orang

- Apa + yang + predikat, apabila subyek itu bukan subyek orang.

Contoh lain:

a. Adik sedang belajar

Maka, pertanyaannya adalah "Siapa yang sedang belajar?" jawabannya tentu adalah Adik. Jadi, subyeknya adalah Adik.

b. Di dalam rumah itu telah ditemukan bom ukuran besar yang siap meledak.

Maka, pertanyaannya adalah "apa yang meledak?". Jawabannya tentu adalah Di dalam rumah itu telah ditemukan bom ukuran besar yang siap meledak

2. Subyek dapat berupa adjektiva, frasa adjektiva, numeralia, frasa numeralia, verba atau frasa verbal. Contoh:

\begin{tabular}{cccc} 
a. & Sehat itu & penting & \multicolumn{2}{c}{ bagi setiap calon presiden } \\
b. & $\frac{\text { Berjalan kaki }}{\mathrm{S} / \text { FV/Pokok }}$ & $\frac{\text { menyehatkan }}{\mathrm{P}}$ & $\frac{\mathrm{K}}{\mathrm{O}}$ \\
c. & $\frac{\text { Dua saja }}{\mathrm{P}}$ & $\frac{\text { sudah cukup }}{}$ &
\end{tabular}

3. S selalu mendahului P.

Contoh,

Nenekku

$\mathrm{S}$

$\underline{\text { cantik sekali }}$

$P$

4. Dalam konstruksi bahasa Indonesia, subjek biasanya terletak di awal kalimat atau di depan predikat. Akan tetapi, dalam konstruksi tertentu, subjek terletak setelah predikat atau setelah keterangan. Contoh:
a.
$\underline{\text { Ada }}$
polemik
dalam partai itu
S
b. Bersama anaknya
$\underline{\text { ia }}$
$S$
$\mathrm{K}$
$\underline{\text { mengadukan nasib }} \quad$ ke komnas HAM
$\mathrm{K}$

5. Subyek biasanya berwujud kategori nomina, kategori frasa nomina, dan kategori verba. Contoh:
a.
Boy
tampan
$\mathrm{S} / \mathrm{N}$
b. Plato itu
S/F.Nomina
pemikir
$P$
c. Menunggu
menyebalkan sekali

${ }^{24}$ Rahardi, Kunjana. Bahasa Indonesia untuk Perguruan Tinggi. (Jakarta: Penerbit Erlangga, 2009). Hal. 78. 
$\mathrm{S} / \mathrm{V} \quad \mathrm{P}$

6. Subyek bahasa Indonesia bercirikan tidak bisa diganti dengan kategori pronomina interogatif (kata ganti tanya).

7. Selain berupa benda/nomina, subyek juga bisa berupa sesuatu yang dibendakan.

Contoh:

- jalannya, akhiran -nya di sini menyatakan kata benda, meskipun kata benda itu menyatakan suatu kerja.

- berperang, bergembira.

8. Tentangnya diberitakan sesuatu. Contoh:

Jalan licin

Berbahaya

S

$P$

Pembicara membicarakan Jalan licin. Bagian ini disebut subyek.

9. Sering terjadi penghilangan $S$ pada kalimat yang terdiri dari dua klausa atau lebih.

Contoh pada kalimat:

Tengah Karmila menangis menghadapi tembok, Bapak Daud masuk diantarsuster Meta.

Tengah Karmila menangis

Klausa 1
$\frac{\text { Bapak Daud masuk }}{\text { Klausa } 3}$

menghadapi tembok

Klausa 2

$\underline{\text { diantar suster Meta }}$

Klausa 4

Klausa 1 merupakan klausa lengkap terdiri dari S dan P. Klausa 2 merupakan klausa tak lengkap hanya terdiri dari P diikuti O. Klausa 3 merupakan klausa lengkap terdiri dari S dan P. Klausa 4 merupakan klausa tak lengkap, terdiri dari $\mathrm{P}$ diikuti Ket. Jadi, terjadi penghilangan pada klausa 2 dan klausa 4.

10. Dalam struktur klausa, $\mathrm{S}$ biasanya bersifat definit atau takrif. Ciri ketakrifan ini merupakan aspek penting dalam menentukan kegramatikalan klausa. Contoh:

Bentuk klausa anak mahasiswa dianggap tidak gramatikal karena unsur anak sebagai S tidak definit. Supaya definit, kata anak seharusnya diikuti oleh demonstrativa inilitu sehingga klausanya menjadi anak itu mahasiswa.

Sebagaimana Putrayasa mengatakan bahwa S diisi oleh konstituen yang takrif $(\mathrm{T})$, sedangkan $\mathrm{P}$ diisi oleh konstituen tidak takrif $(\mathrm{TT})^{25}$. Contoh:
a.
Iwan
Pelukis

${ }^{25}$ Ida Bagus Putrayasa. Jenis Kalimat dalamBahasa Indonesia. (Bandung: Refika Aditama, 2012). Hal. 125. 
$\begin{array}{ccc}\text { b. } & \mathrm{T} & \mathrm{TT} \\ \text { c. } & \frac{\text { Pelukis }}{\mathrm{TT}} & \frac{\text { Iwan }}{\mathrm{T}} \\ \mathrm{T} & \frac{\text { Pelukis itu }}{\mathrm{T}} & \text { Iwan }\end{array}$

Kridalaksana menjelaskan ketakrifan adalah hal yang bersangkutan dengan sifat nomina atau frase nominal yang referennya telah ditentukan atau dianggap sama-sama diketahui oleh pembicara dan pendengar dalam situasi komunikasi ${ }^{26}$. Bagian kalimat yang takrif biasanya mengandung kata itu, sang, dsb. atau berupa nama diri.

Rahardi menambahkan bahwa untuk nama-nama orang dan kata ganti orang atau pronomina, tidak perlu lagi ditambah 'ini', 'itu', atau 'tersebut'. Alasannya, bentuk-bentuk bahasa seperti disebutkan diatas itu sudah berciri takrif, sudah berciri definite atau pasti ${ }^{27}$.

11. Bagian yang menjadi subjek kalimat dapat juga ditandai dengan 'yang' kemudian diikuti keterangan subjek itu.

Contoh:

Anak yang nakal itu menangis tidak henti-hentinya dari tadi

S

$\mathrm{P}$

K

\section{Perluasan subyek inti kalimat}

1. Perluasan dengan atributif/keterangan

Contoh: Cerita itu menegangkan

Subyek kalimat inti diatas adalah Cerita itu. Subyek tersebut dapat diperluas, misalnya menjadi:

- Cerita itu // P

- Cerita musibah itu // P

- Cerita musibah Situ itu // P

- Cerita musibah Situ Gintung itu // P

- Cerita musibah Situ Gintung di Ciputat itu // P

- Cerita musibah Situ Gintung di Ciputat, Tangerang Selatan itu // P

- Cerita musibah Situ Gintung di Ciputat, Tangerang Selatan, Banten itu // P

Keterangan Subyek inti itu, sesuai dengan adanya perkecualian Hukum DM, dapat pula diletakkan di depan Subjek Inti.

Misalnya menjadi:

- Semua cerita ... // P

- Sebagian besar cerita ... // P

${ }^{26}$ Harimurti Kridalaksana. Kamus Linguistik. (Jakarta: Penerbit Gramedia Pustaka Utama, 2011). Hal. 120.

${ }^{27}$ Kunjana Rahardi. Bahasa Indonesia untuk Perguruan Tinggi. (Jakarta: Penerbit Erlangga, 2009). Hal. 78. 
- Hampir seluruh bagian cerita ... // P

Kesimpulan: keterangan/atributif untuk subjek inti dapat diletakkan di depan atau di belakang $S$ atau sekaligus di depan dan di belakang $S$ inti.

2. Perluasan dengan aposisi/keterangan pengganti

Atributif dan aposisi mempunyai kesamaan fungsi, yaitu samasama menerangkan / memberi keterangan pada Subjek. Perbedaannya terletak pada:

1) Aposisi selalu terletak dibelakang subjek inti

2) Kecuali bertugas menerangkan subjek inti, aposisi berfungsi juga sebagai pengganti subjek inti sendiri, karena itu aposisi juga disebut Keterangan Pengganti;

3) Aposisi selalu terletak dibelakang kata yang diinginkan, biasanya diceraikan dengan koma;

4) Aposisi terdiri dari kata atau kelompok kata;

5) Aposisi berfungsi berfungsi menerangkan kata benda, jadi juga bisa menjadi aposisi Predikat dan Objek.

Contoh aposisi yang berwujud kelompok kata

1) Raminra, Putra pertamanya, sudah lulus ujian akuntansi.

2) Paramita, putri kedua Pak Bagus, sedang mengikuti tes di Unud

3) Teuku Wisnu, pemain sinetron terfavorit tahun 2009, berasal dari Aceh.

Contoh aposisi predikat

1) Tamunya (ialah) para pejabat tinggi, peninjau pembangunan pabrik baja itu ( $\mathrm{P}=$ kata benda)

2) Bala bantuannya tiga kompi, pasukan gerak cepat pimpinan seorang Kapten ( $\mathrm{P}=$ Kata Bilangan)

Contoh aposisi objek

1) Ria mengembalikan buku, catatan bahasa Indonesia (Aposisi untuk objek penderita)

2) Hutan itu, dibuka oleh transmigran, petani-petani muda asal Bali (Aposisi objek pelaku)

3) Jawaban kilat itu dikirimkan kepada nakhoda, seorang nelayan tua itu (Aposisi objek berkepentingan).

Keterangan:

1. Subjek, Predikat, dan Objek yang diberi aposisi bisa dihilangkan tanpa mengubah arti kalimat, karena kedudukannya bisa diganti oleh aposisinya masing-masing, sehingga, misalnya kalimat contoh yang pertama bisa menjadi:

- Putri tunggalnya sudah lulus ujian bidan

- Yang menjadi harapan keluarganya sudah lulus ujian bidan 
2. Untuk memberikan keterangan tambahan pada $\mathrm{S}, \mathrm{P}$, atau $\mathrm{O}$ bisa juga dengan mengkombinasikan atribut dan aposisi.

Misalnya:

Semua pedagang eceran, yang tidak mempunyai izin usaha, harus mendaftarkan diri. (kalimat inti: Pedagang) mendaftarkan diri.

\section{Analisis Perbandingan}

Perbandingan yang akan disajikan ialah tentang persamaan dan perbedaan antara subyek dalam bahasa arab dan bahasa Indonesia pada beberapa kategori, yaitu: Pengertian, jenis, karakteristik, dan unsur pembentuk subyek. Berikut akan dipaparkan perbandingan keduanya serta bahasan persamaan dan perbedaannya.

Pengertian subyek

Pengertian subyek dalam bahasa Indonesia adalah unsur yang berfungsi sebagai pokok pembicaraan suatu kalimat. Sedangkan dalam bahasa Arab subyek dipadankan dengan musnad ilaihi yaitu maa hukimat 'alaihi bisyai maksudnya adalah segala sesuatu yang dihukumi atau ditandai oleh suatu hal. Jika kita fahami baik-baik, inti maksud dari keduanya sama, pokok pembicaraan dengan sesuatu yang ditandai. Sesuatu yang ditandai, artinya ia juga menjadi pokok. Hanya saja nanti akan terdapat beberapa perbedaan mungkin dari segi karakteristik atau yang lainnya.

Jenis Subyek

Subyek dalam bahasa Indonesia hanya memiliki satu jenis dan satu nama. Sedangkan dalam bahasa Arab subyek memiliki ragam jenis dan sinonim yaitu fa'il, na'ib fa'il,Mubtada', Isim Kaana wa akhwatuha, Isim Inna wa akhwatuha, Isim huruf yang beramal seperti laisa, dan Isim La an-nafiyah lil jinsi. Dalam poin ini jelas sekali perbedaannya.

Karakteristik Subyek

Sebagaimana dijelaskan dimuka, pada dasarnya semua bahasa adalah sama karena di dasari satu sistem yang universal. Namun, setiap bahasa memiliki karakteristik yang berbeda. Karakteristik subyek dalam bahasa Indonesia yaitu, diketahui dengan menggunakan kata tanya Apa dan siapa, S selalu mendahului $\mathrm{P}$, dalam konstruksi tertentu subyek terletak setelah predikat atau setelah keterangan, subyek dalam bahasa Indonesia tidak bisa diganti dengan kategori pronomina interogatif (kata ganti tanya), tentangnya diberitakan sesuatu, sering terjadi penghilangan $S$ pada kalimat yang terdiri dari dua klausa atau lebih, dalam struktur klausa, $\mathrm{S}$ biasanya bersifat definit atau takrif, dan subyek dapat ditambah dengan menggunakan kata 'yang'. Sedangkan karakteristik subyek dalam bahasa Arab yaitu, harus beri'rob rafa', terkadang bisa nashab dan terkadang bisa jar, pada jumlah fi'liyyah, subyek (musnad ilaihi) terletak di akhir setelah predikat (musnad), sebaliknya dalam jumlah ismiyyah subyek (musnad ilaihi) terletak di awal baru kemudian 
predikat (musnad), subyek merupakan bagian yang harus ada dalam jumlah, subyek bisa ditiadakan jika hanya untuk menjawab pertanyaan, antara subyek (musnad ilaihi) dan predikat (musnad) saling mempengaruhi dalam jenis dan kuantitasnya, memiliki makna apa dan siapa, dan subyek dalam jumlah ismiyyah harus ma' rifat.

Ada beberapa persamaan antara keduanya yaitu, memiliki makna apa dan siapa, subyek dalam klausa harus definit dalam bahasa Arab ia harus ma'rifat dalam jumlah ismiyyah. Terkadang terletak setelah predikat namun bisa juga sebaliknya.

Unsur Pembentuk Subyek

Subyek dalam bahasa Indonesia dibentuk oleh beberapa jenis kata yang menjadi unsur pembentuknya yaitu adjektiva, frasa adjektiva, numeralia, frasa numeralia, verba, frasa verbal, nomina, frasa nomina, sesuatu yang dibendakan, dan konstituen yang takrif. Sedangkan dalam bahasa Arab disusun oleh isim shorih, isim dhomir, isim muawwal bishorih, dan syibhul jumlah.

\section{Kesimpulan}

Dari hasil pembahasan diatas, diperoleh kesimpulan bahwa pada dasarnya subyek dalam bahasa Arab dan bahasa Indonesia adalah sama. Karena sama-sama merupakan inti pembicaraan. Selain itu, keduanya harus ada dalam kalimat, dengan kata lain menjadi unsur yang penting dalam kalimat. Jika tidak ada subyek, maka tidak akan disebut kalimat atau klausa.

Meski demikian tetap ada beberapa hal yang berbeda antara keduanya, karena bahasa yang berbeda, budaya dan negara yang jelas berbeda. Misalnya, dalam bahasa Arab terdapat pembahasan i'rob yang menjadi salah satu karakteristik subyek dalam bahasa Arab. Sementara dalam bahasa Indonesia tidak ada istilah i'rob dan subyek tidak dipengaruhi i'rob. Kemudian, dalam bahasa Indonesia subyek tidak dipengaruhi oleh predikat, kuantitas kata, maupun jenis kata, karena tidak ada jenis kata dalam bahasa Indonesia. Beda halnya dalam bahasa Arab, subyek dan predikat sangat berpengaruh baik dari segi jenisnya maupun kuantitasnya.

Untuk unsur pembentuk subyek sama-sama bisa dibentuk dari adjektif, frasa adjektif, nomina, frasa nomina. Hanya saja mungkin untuk istilahnya berbeda dalam bahasa Arab. Namun, ada juga perbedaan unsur pembentuknya seperti dalam bahasa Indonesia subyek bisa dibentuk oleh verbal dan frasa verbal, sedangkan dalam bahasa Arab tidak bisa. Karena kata kerja dalam bahasa Arab harus dibendakan terlebih dahulu untuk bisa menjadi subyek, lalu kemudian itu yang disebut dengan masdar. 


\section{Daftar Pustaka}

Al-Gulayaini, Mushtofa. 2005. Jami'uddurus Al-Lughah Al-'Arobiyah. Kairo: daarul hadis 2007. Ad-Durusul 'arobiyah. Libanon: daarul kutub

Asrori, Imam. 2004. Sintaksis Bahasa Arab. Malang: Penerbit Misykat.

Azizah, Fitria Rif'atul. 2016. Analisis Pemikiran Ibnu Khaldun Terhadap Direct Method Dalam Pembelajaran Bahasa Asing. Skripsi. Cirebon: IAIN Syekh Nurjati (Tidak dipublikasi)

Chaer, Abdul. 2009. Buku Sintaksis Bahasa Indonesia. Jakarta: PT. Rineka Cipta.

Dahlan, Ahmad Zaini. Matan al-ajurumiyah. Surabaya: Maktabatu Muhammad bin nabhan wa Awladihi

Hermawan, Acep. 2011. Metodologi Pembelajaran Bahasa Arab. Bandung: PT. Remaja Rosdakarya.

Holilurrohman. 2012. Panduan Membaca dan Memahami Kitab Kuning. Bandung: Arfino Raya.

Khairah, Miftahul \& Sakura Ridwan. 2014. Sintaksis Memahami Satuan Kalimat Perspektif Fungsi. Jakarta: Bumi Aksara

Khoironi, Agus Shohib. 2007. Awdhohul Manahij fii Mu'jami al-lughah al-'arobiyah. Jakarta: WCM Press

Kosasih. 2002. Kompetensi Ketatabahasaan Cermat Berbahasa Indonesia. Bandung: CV YRAMA WIDYA

Kridalaksana, Harimurti. 2011. Kamus Linguistik. Jakarta: Penerbit Gramedia Pustaka Utama

Lubis, Hamid Hasan. 1994. Glosarium Bahasa dan Sastra. Bandung: Angkasa

Muslich, Masnur. 2014. Garis-garis Besar Tata Bahasa Baku Bahasa Indonesia. Malang: Reflika Aditama

Nimas, Ikraam. 2014. Makalah Bahasa Indonesia Kalimat Efektif. Paper Academia Edu (dipublikasi)

Putrayasa, Ida Bagus. 2012. Jenis Kalimat dalamBahasa Indonesia. Bandung: Refika Aditama

. 2010. Analisis Kalimat Fungsi Kategori dan Peran. Bandung: Refika Aditama

Rahardi, Kunjana. 2009. Bahasa Indonesia untuk Perguruan Tinggi. Jakarta: Penerbit Erlangga.

Ramlan, M. 2005. Sintaksis. Yogyakarta: CV Karyono

Syamsuddin, Ibrahim. 1971. Marja'u ath-thullabi Fiji qawa'id al-lughah. Libanon: daarul kutub al-‘alamiyah

Tarigan, Henry Guntur. 2009. Pengajaran Sintaksis. Bandung: Angkasa

Tha'imah, Rusydi Ahmad. 1946. Al-Marja' fii ta'liimi al-lughah al-'arobiyyah. Mesir: Jami'ah Ummul Qura. 